J. Product. \& Dev., 26(3):447-462(2021)

\title{
ANTIFUNGAL ACTIVITY OF SOME ESSENTIAL OILS AGAINST POST-HARVEST FRUIT ROT OF SWEET PEPPER
}

\author{
Amira M. Tawfik', Sayed E. Younis; Ali M. Koriem and M. I. Elian \\ Department of Plant Production, Faculty of Technology \& Development, \\ Zagazig University, Egypt. \\ Corresponding author E-mail: amt2222@yahoo.com Mobile: +201062951792
}

\section{ABSTRACT}

A laboratory experiment was conducted using some essential oils, i.e., Eucalyptus globulus, Eugenia caryophyllata, Cinnamomum cassia and Zingiber officinale to study their effects at different concentrations $(1,2,3,4 \% v / v)$ on the radial growth and spore germinations of, Ulocladium chartarum, Aspargillus niger, Fusarium semitectum and Geotrichum candidum, which were Isolated and identified of postharvest rots pepper fruits obtained from local markets using potato dextrose agar. The obtained results generally indicated that the tested essential oils significantly inhibit growth of the tested fungi. Eugenia caryophyllata oil was the most effective one, followed by Eucalyptus globulus of all tested concentrations, flowed by Cinnamomum cassia and Zingiber officinale oils at high concentrations. Moreover, some of the tested fungi were affected by all used essential oils, while Aspargillus niger was the most resistant fungi.

Conclusively; it could be concluded that the tested essential oils were effectively inhibited the growth of the tested fungi that cause postharvest fruit rot diseases of sweet pepper at different concentrations tested (1, 2, 3, 4\%).

Keywords: Essential oil, postharvest, pepper, fungi.

\section{INTRODUCTION}

Sweet pepper (Capsicum annuum L.) is one of the most important vegetable crops (Berke, 2002). Nevertheless, it is a very perishable vegetable with a short shelf life and high susceptibility to fungal diseases (Hardenburg et $a l ., 1990)$, and popular vegetable crops are grown for both local consumption and exportation. Peppers contain a nutrient list of plant nutrient that is found to have disease preventing and health-promoting properties (Howard et al., 2000) because peppers contain phytochemicals which assist in the prevention of 
cancer, stroke and other diseases when consumed in diets (Ademoyegun et al., 2011). Moreover, pepper is essential as a food, medicinal and industrial crop (Ashilenje, 2013).

In a related context, pepper fruits commonly encounter postharvest problems, such as quality degradation, chilling injury when stored below $7^{\circ} \mathrm{Cand}$ shriveling associated with rapid loss of weight (Maalekuu et al., 2002; Meir et al., 1996; Paull, 1990; Smith et al., 2006). Previous investigators showed that sweet peppers are harvested at the mature green stage and storage at $7.5^{\circ} \mathrm{Cor}$ above is recommended to minimize the risk of chilling injury (Kader, 2002; Lin, 2005; Meir et al., 1996). This may be because a chilling injury occurs at lower temperatures and decay was higher at $10^{\circ} \mathrm{C}$ (Lin, 2005).

Moreover, sweet pepper is one of the most important extracts from the pepper is also used as a botanical pesticide for the control of insect pests and diseases of economic crops in organic farming systems. Peppers are used in pickles, for flavoring sauces and in canned products. They are also used for confectionery products like bread, meat pie, and burger. The fungal pathogens of postharvest rots of pepper were carried out on rotted pepper fruits obtained from markets using potato dextrose agar. Aspergillus niger was frequently isolated with $34.7 \%$, followed by Aspergillus flavus, Botrytis cinerea, Colletotrichum capsici and Phytophthora capsici with $21.3 \%, 20 \%, 10 \%$ and $10.7 \%$ respectively (Sarkhosh et al., 2017). On the other hand, essential oils are promising alternative compounds which have an inhibitory activity on the growth of pathogens. Essential oils could be used in plant disease control as the main or as adjuvant antimicrobial compounds (Kaur \& Arora, 1999). It established that some plants contain compounds able to inhibit microbial growth (Naqui et al., 1994).

Essential oils are gaining popularity and drawing the attention of scientists around the world cause to their biodegradable, eco-friendly, economical and safe properties. Vaughn \& Spencer (1991) and Caccioni \& Guizzardi (1994, (Macias et al., (1997). reported that the essential oils exhibit antimicrobial, allelopathic, antioxidant and bio-regulatory properties. Therefore essential oils can be ideal candidates for use as pesticides Also, Wilson et al. (1997a, b), Meepagala et al. (2002) and Imelouane et al. (2009) mentioned that the essential oils obtained from different plants and have indicated fungicidal properties. It suppressed fungal growth and development in vitro and in vivo in different fresh produce. Also, it being safer for the environment than synthetic fungicides. 
Several essential oils currently in use, are approved by the FDA as flavoring agents, and also were widely used in the food industry. Their FDAapproved status and their wide availability have facilitated the rapid commercialization of essential oils-based pesticides (pests and insects). Koul et al. (2008) confirmed that the continuous application of synthetic fungicides could cause resistance to developing in fungal strains while it is likely that the resistance will develop more slowly during the application of bio-based essential oils because of the composition of the different chemical components that characterize these oils.

Besides, the Essential oils contain compositions of terpenes, sesquiterpenes, ketones and phenolic components . Thyme oil was reported to exhibit $100 \%$ control of B. cinerea, Rhizopus stolonifer, Alternaria alternata (Plotto et al., 2003) and C. gloeosporioides, (Sellamuthu et al., 2013) during in vitro tests. 'Satsuma' mandarins inoculated with Geotrichum citri-aurantii and treated with thyme oil reduced the incidence of sour rot to $14.1 \%$, whereas the untreated control fruit revealed an incidence of $78.1 \%$. In naturally infected fruit, thyme oil reduced the decay by $76 \%$ after 30 days at $20^{\circ} \mathrm{C}$. In vitro tests also revealed that cinnamon oil effectively controlled $C$. gloeosporioides in bananas (Maqbool et al., 2010).

Therefore, the objectives of this study were to evaluate the effects of antifungal activity of some essential oils against post-harvest fruit rot of pepper (Capsicum annuum L.) and evaluate their effects on the development and suppression of this pepper fruits rot diseases.

\section{MATERIALS AND METHODS}

\section{Fungal isolate}

The isolates of Ulocladium chartarum, Aspargillus Niger, Fusarium semitectum and Geotrichum candidum were obtained from an infected sweet pepper fruit and cultured on potato dextrose agar. The identification was confirmed by the Department of Disease Survey and Mycology, Plant Pathology Institute, Agricultural Research Center, Giza, Egypt.

\section{Pathogenicity test}

To test the pathogenicity of various fungi isolated, the approach of Balogun et al. (2005) was employed. Healthy matured pepper fruits, California wonder, Bravo 'Triple 4' Capino and Cadia were surfaced sterilized with $0.5 \%$ sodium hypochlorite for 30 seconds and then rinsed in three changes of sterile distilled water. With a $5 \mathrm{~mm}$ diameter flame sterilized corn 
borer, cylindrical cores were removed from each fruit then inoculated aseptically with $5 \mathrm{~mm}$ diameter disc from the edge of 7 day-old fungal culture of the tested isolate. Vaseline jelly was smeared to completely seal the surface of each of the inoculated pepper fruit to prevent external infection before incubating for 10 days, three replicates were used. The controls were inoculated with the disc of solidified potato dextrose agar media.. Rot symptoms developed with different fungal isolates were compared to the natural original rot. The pathogens were re-isolated and identified using the same procedures described above.

\section{Estimation of rot severity}

Observation for the level of fungal growth and fruit rot was made daily for 10 days and results were recorded, as percentage rot severity according to adopting the method of Balogun et al., (2005). In this study, a fungus was considered pathogenic on the fruit if new mycelia emerged and extended radially and upwards from the originally inoculated disc and became visible outside the original wound hole on the fruit surface thereby causing fruit rot. On this basis, growth and pathogenicity were rated as follows; low (rot covered less than $25 \%$ of the fruit surface); medium (covered $25-50 \%$ of the fruit surface); high (51-75\% covered) and very high (covered $75 \%$ and above). Percentage of rot severity was determined using the formula below.

\section{Essential oils}

Essential oils (Table 1) of Eucalyptus globulus, Eugenia caryophyllata, Cinnamomum cassia and Zingiber officinale were purchased from International Flavors and Plant oils Inc., Giza, Egypt, and from Delta Aromatic Co., Cairo, Egypt. These essential oils were stored in dark bottles at $4^{\circ} \mathrm{C}$ for further studies.

Table (1): Essential oils and their source p plants used to control sweet peppers fruit rot fungal disease.

\begin{tabular}{lccc}
\hline \multicolumn{1}{c}{ Scientific name } & Family & Common name & Tissue type \\
\hline Eucalyptus globulus Labill & Myrtaceae & Eucalyptus & Leaves \\
Eugenia caryophyllata Thunb & Myrtaceae & Clove & Flower buds \\
Cinnamomum cassia (Nees\& T. & Lauraceae & Cinnamon & Dried bark \\
Nees) & Zingiberaceae & Ginger & Rhizome \\
Zingiber officinale Roscoe & &
\end{tabular}

\section{Effect of essential oils on fungal growth}


The essential oils, i.e., Eucalyptus globulus, Eugenia caryophyllata, Cinnamomum cassia and Zingiber officinale at different concentrations (1\%, $2 \%, 3 \%$ and $4 \%$. v/v) were evaluated for their inhibitory effect on fungal radial growth, through in vitro. Emulsified stocks at high concentrations of tested essential oils were prepared by dissolving in sterilized distilled water. A few drops of the emulsifier Tween 20 (Sigma Co.) were added to the essential oil volumes to obtain an emulsion feature.

Different volumes of the essential oil emulsion were added to conical flasks containing $100 \mathrm{ml}$ of sterilized potato dextrose agar media before solidification, to obtain the proposed concentrations. The supplemented media were poured into Petri plates $(10 \mathrm{~cm} \varnothing)$ about $20 \mathrm{ml}$ each. Then plates were individually inoculated at the center with equal disks $(5 \mathrm{~mm} \varnothing)$ of 10-days old culture of the tested fungi. A set of inoculated plates free of tested essential oils used as controls. Five plates were used as replicates for each particular treatment. Inoculated plates were incubated at $25-28{ }^{\circ} \mathrm{C} \pm 1^{\circ}$. The average linear growth of fungi tested was calculated when controls reached full growth.

\section{Effect of essential oils on spore germination:}

Spore suspensions of each pathogen $(1 \mathrm{ml}$; 9X 105 spore $/ \mathrm{ml})$ were placed in micro-tubes containing $5 \mathrm{ml}$ of potato dextrose broth amended with test salt or un-amended (control). The $\mathrm{pH}$ of potato dextrose broth varied with the salt used and was not changed unless stated otherwise. Micro-tubes were incubated at $24{ }^{\circ} \mathrm{C}$ for one day. The germination of spores was determined using a hemocytometer. Spores with germ tubes at least half the length of the spore was considered as germinated. Inhibition of spore germination was calculated as follows:

ISG $=\frac{\text { control spore germination }- \text { salt amended spore germination }}{\text { control spore germination }} \times 100[E q .2]$

Three replicates were used.

\section{Statistical analysis:}

Statistical analyses of all experimental data were done using the statistical software SAS package, all comparisons were first subjected to oneway analysis of variance (ANOVA).

Significant differences between treatment means was determined using Duncan's multiple range test at $\mathrm{P}<0.05$ as the level of the significance (Duncan, 1955). 


\section{RESULTS AND DISCUSSION}

The obtained result as shown in Table 2 illustrates that test of the pathogenicity of the fungus post the inoculation process during several different days. Data indicated that the process of pathogenicity test was more effective at seven and ten days post inoculation with all tested fungi except with Geotrichum candidum.

Data presented in Table 3 indicated a significant effects of Eucalyptus globulus oil on the radial growth of all tested fungi when used at concentrations of 3 and $4 \%$, and its effects were clear on the growth of Geotrichum candidum and Aspergillus niger. While the Eugenia caryophyllata oil significantly reduced the radial growth of all tested fungi. Cinnamomun cassia oil at $4 \%$ was effective on radial growth of Geotrichum candidum and Aspergillus niger, but Zingiber officinale had a relatively limited effect compared to other oils tested. Geotrichum candidum was the most affected fungi. The obtained results in Table 4 indicated that the most effective oil in inhabited radial growth of the tested fungi was Eugenia caryophyllata oil because it completely inhibited growth of all tested fungi compared to the control treatment.

The spore germination of the studied fungi was affected by the Eucalyptus globulus oil (Table 5) at concentrations of 3 and 4\% compared to the lower concentrations, while the Eugenia caryophyllata oil completely inhibited spore germination of fungi tested with all used concentrations. In contrast, Cinnamomun cassia and Zingiber officinale oils had a relatively limited effect on spore germination compared to the control treatment. Moreover, the obtained results in Table 6 indicated that inhibition percentage of spore germination of the studied fungi. Eugenia caryophyllata oil in all its concentrations was the most effective, followed by Eucalyptus globulus oil with a concentration of 3 and 4\%, and Cinnamomun cassia oil at 4\%, .Zingiber officinale oil has an effective impact but it is relatively limited compared to other studied oils.

Results of the statistical analysis presented in Table 7 indicated the effect used oils at concentrations of 1,2, 3 and $4 \%$ in had a clear significant effects on inhibition growth of tested fungi, especially the higher effect of Eugenia caryophyllata oil, followed by Eucalyptus globulus oil, and the weakest of them is of Zingiber officinale oil. On the other side, results of the 
concentrations of used oils presented in the same table for the statistical analysis indicated that the higher concentration of these oils is the most

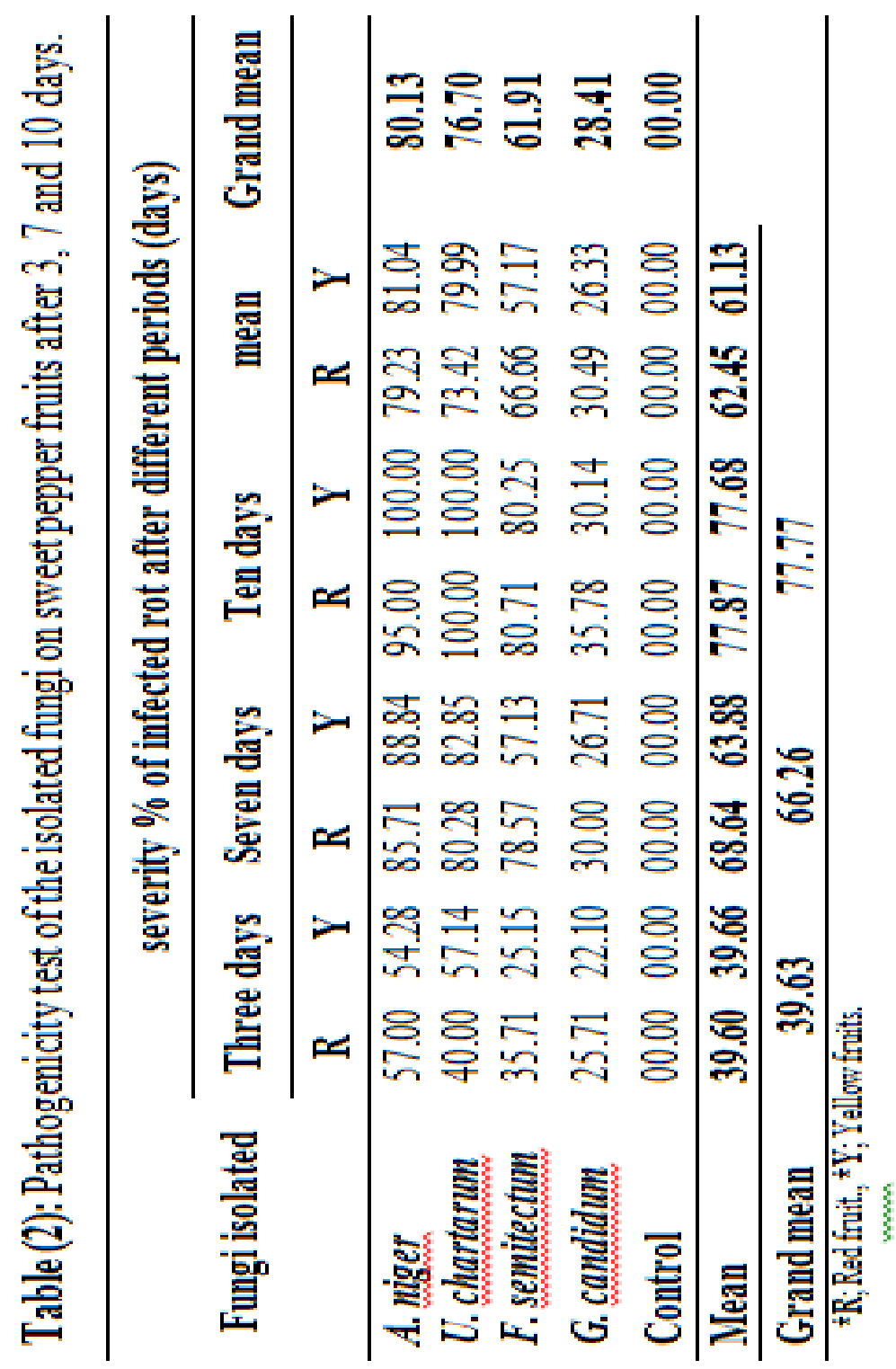



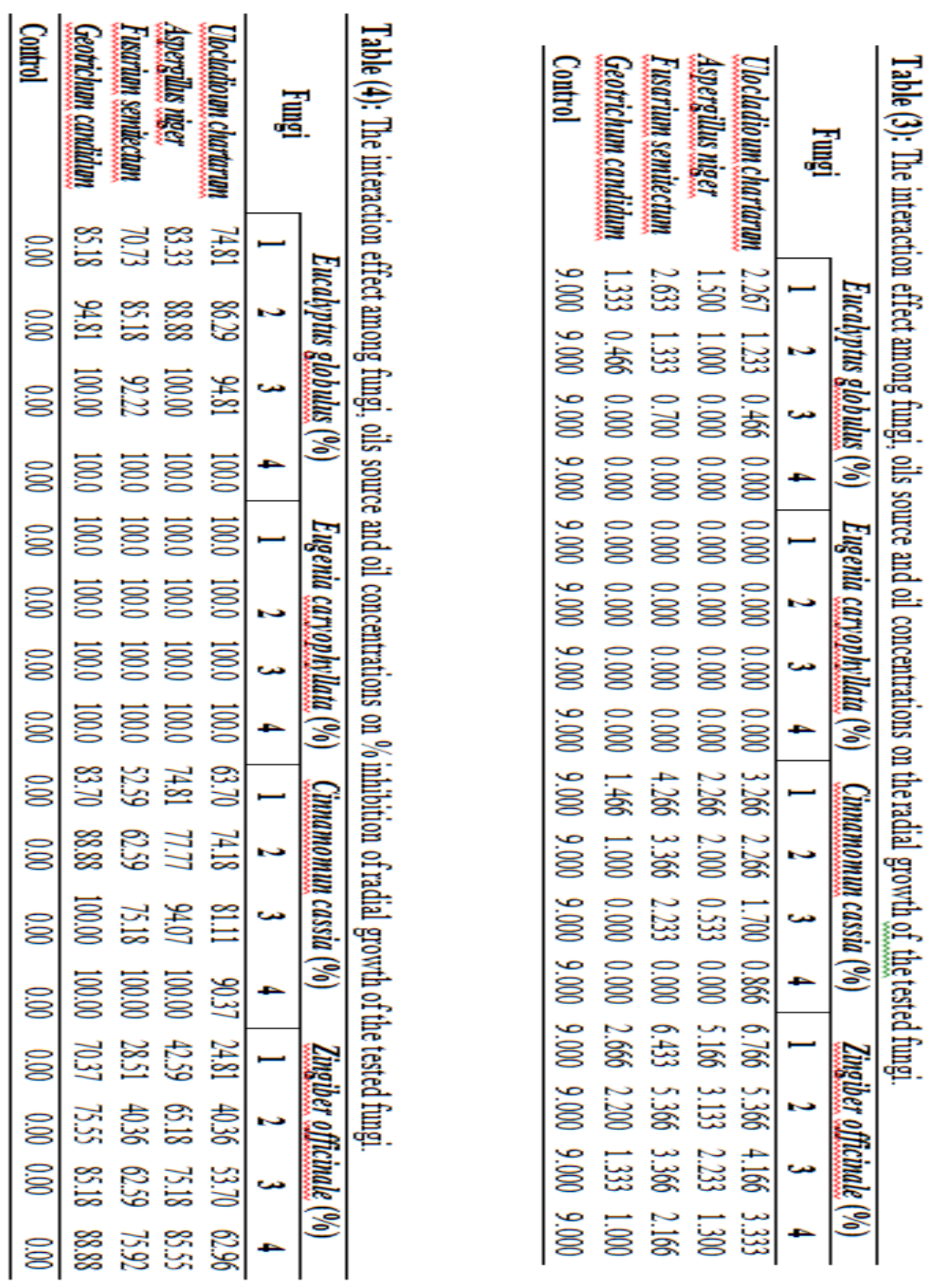

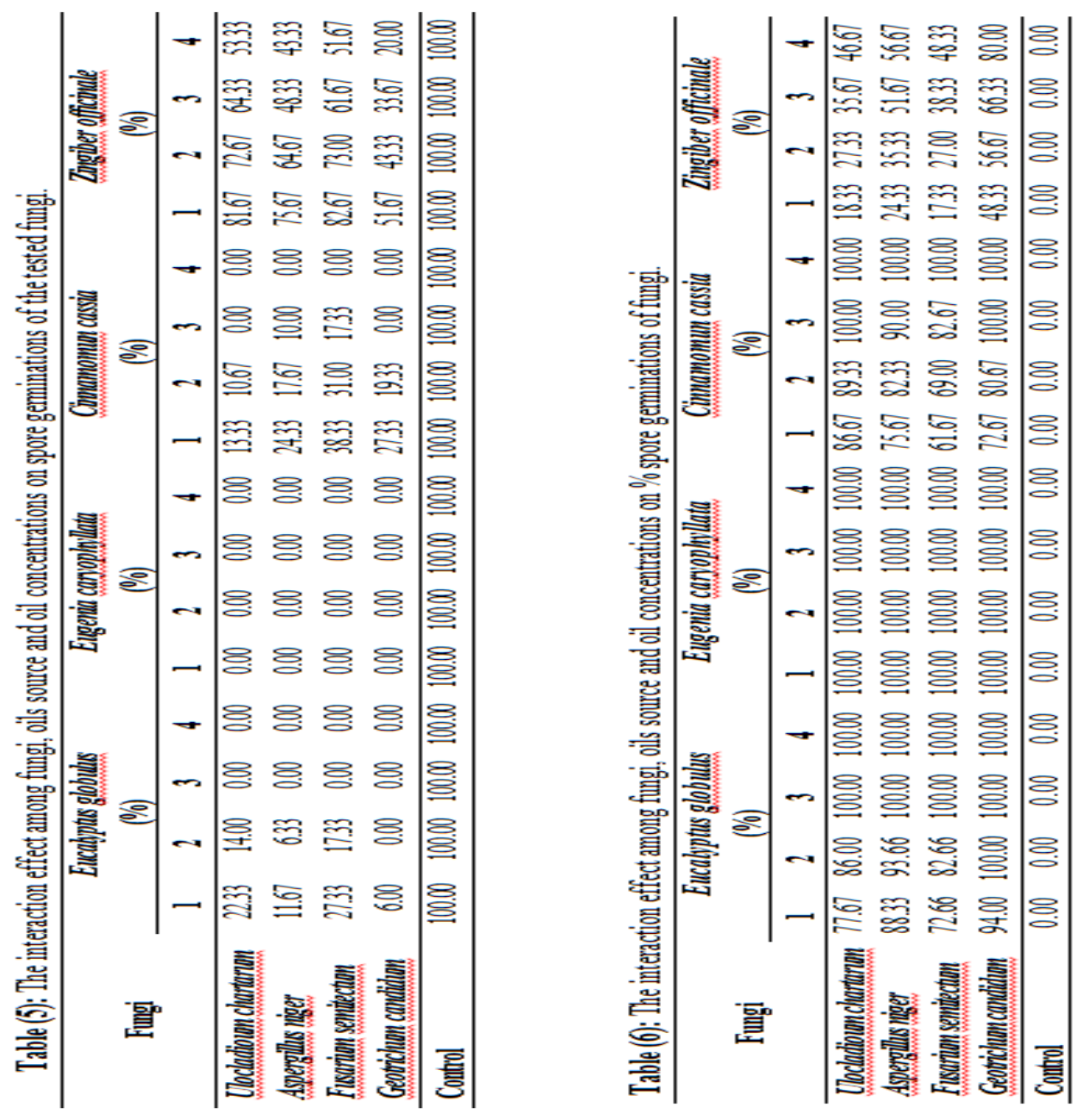
Table (7): Effect of the tested essential oils and with different concentrations on the radial growth of the tested fungi, inhibition the radial growth\% of fungi, spore germination and inhibition of spore germination $\%$ of the studied fungi.

\begin{tabular}{|c|c|c|c|c|}
\hline Treatments & $\begin{array}{l}\text { Radial } \\
\text { growth of } \\
\text { fungi }\end{array}$ & $\begin{array}{l}\text { Inhibition } \\
\text { radial } \\
\text { growth of } \\
\text { fungi \% }\end{array}$ & $\begin{array}{c}\text { Spore } \\
\text { germination }\end{array}$ & 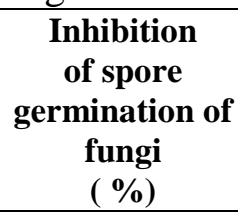 \\
\hline \multicolumn{5}{|l|}{ Fungi $(A)$} \\
\hline Ulocladium chartarum & $1.981^{\mathrm{a}}$ & $77.983^{\mathrm{d}}$ & $20.771^{b}$ & $79.229^{c}$ \\
\hline Aspergillus niger & $1.196^{\mathrm{c}}$ & $86.710^{\mathrm{b}}$ & $18.875^{\mathrm{c}}$ & $81.125^{\mathbf{b}}$ \\
\hline Fusarium semitectum & $1.992^{\mathbf{a b}}$ & $77.868^{\mathrm{c}}$ & $25.021^{\mathrm{a}}$ & $74.979^{\mathrm{d}}$ \\
\hline Geotrichum candidum & $0.717^{\mathrm{d}}$ & $92.034^{\mathrm{a}}$ & $12.583^{\mathrm{d}}$ & $87.417^{\mathrm{a}}$ \\
\hline LSD $(0.05)$ & 0.052 & 0.573 & 0.665 & 0.665 \\
\hline \multicolumn{5}{|l|}{ Oils $(B)$} \\
\hline $\begin{array}{l}\text { Eucalyptus globulus } \\
\text { (Eucalyptus) }\end{array}$ & $0.808^{c}$ & $91.015^{\mathrm{b}}$ & $6.563^{\mathrm{c}}$ & $93.438^{\mathbf{b}}$ \\
\hline $\begin{array}{l}\text { Eugenia caryophyllata } \\
\text { (Clove) }\end{array}$ & $0.000^{d}$ & $100.000^{\mathrm{a}}$ & $0.000^{d}$ & $100.000^{\mathrm{a}}$ \\
\hline $\begin{array}{l}\text { Cinnamomun cassia } \\
\text { (Cinnamon) }\end{array}$ & $1.577^{\mathrm{b}}$ & $82.474^{\mathrm{c}}$ & $13.083^{\mathrm{b}}$ & $86.917^{\mathfrak{c}}$ \\
\hline $\begin{array}{l}\text { Zingiber officinale } \\
\text { (Ginger) }\end{array}$ & $3.500^{\mathrm{a}}$ & $61.106^{\mathrm{d}}$ & $57.604^{\mathrm{a}}$ & $42.396^{\mathbf{d}}$ \\
\hline LSD (0.05) & 0.052 & 0.573 & 0.665 & 0.665 \\
\hline \multicolumn{5}{|l|}{ Concentrations $(C)$} \\
\hline $1 \%$ & $2.502^{\mathrm{a}}$ & $72.196^{\mathrm{d}}$ & $28.896^{\mathrm{a}}$ & $71.104^{\mathrm{d}}$ \\
\hline $2 \%$ & $1.796^{\mathrm{b}}$ & $80.042^{\mathrm{c}}$ & $23.125^{\mathrm{b}}$ & $76.875^{\mathrm{c}}$ \\
\hline $3 \%$ & $1.046^{\mathrm{c}}$ & $88.378^{\mathrm{b}}$ & $14.708^{\mathrm{c}}$ & $85.292^{b}$ \\
\hline $4 \%$ & $0.542^{d}$ & $93.980^{\mathrm{a}}$ & $10.521^{\mathrm{d}}$ & $89.479^{\mathrm{a}}$ \\
\hline LSD (0.05) & 0.052 & 0.573 & 0.665 & 0.665 \\
\hline \multicolumn{5}{|l|}{ Interactions } \\
\hline $\mathrm{A} \times \mathrm{B}$ & ** & ** & $* *$ & $* *$ \\
\hline $\mathrm{A} \times \mathrm{C}$ & $* *$ & $* *$ & $* *$ & $* *$ \\
\hline $\mathrm{B} \times \mathrm{C}$ & $* *$ & $* *$ & $* *$ & $* *$ \\
\hline $\mathrm{A} \times \mathrm{B} \times \mathrm{C}$ & $* *$ & $* *$ & $* *$ & $* *$ \\
\hline \multicolumn{5}{|l|}{ LSD of interactions: } \\
\hline $\mathrm{A} \times \mathrm{B}=$ & 0.1732 & 1.9235 & 1.1170 & 1.11705 \\
\hline $\mathrm{A} \times \mathrm{C}=$ & 0.8384 & 9.3156 & 4.8506 & 4.8506 \\
\hline $\mathrm{B} \times \mathrm{C}=$ & 1.7703 & 19.671 & 17.1345 & 17.1345 \\
\hline $\mathrm{A} \times \mathrm{B} \times \mathrm{C}=$ & 0.9062 & 10.0714 & 10.9033 & 10.9033 \\
\hline
\end{tabular}

** $\mathrm{P}<0.01$ 
effective on inhibition of radial growth of fungi. The interaction among studied factors, results of the statistical analysis indicated to a significant interaction relationship among the studied factors, and all these interactions were significant. Based on the obtained results, it can be concluded that the used oils have important effect in inhibiting the growth and spores ermination of fungi, especially Eugenia caryophyllata oil, Eucalyptus globulus at all used concentrations, and $4 \%$ concentration of the Cinnamomun cassia and Zingiber officinale oil were the most effective.

Similar results with Sarkhosh et al. (2017) who indicated that Cinnamomun cassia oil completely inhibited the mycelial growth of some fungi i.e., F. solani at a concentration of $0.1 \%$, and the highest concentration applied $(0.15 \%)$ completely inhibited growth of $P$. palmivora. It also observed that cinnamon oil inhibited growth of Botryosphaeria spp. and $C$. gloeosporioides substantially. Also broad-spectrum anti-fungal activity and control of late leaf spot and crown rot in peanut, of Cinnamomun cassia oil was foun. It inhibited in vitro spore germination of the Cercospora arachidicola, Phaeoisariopsis personata, and Puccinia arachidis and reduced the incidence of crown rot caused by Aspergillus niger (Kishore \& Pande 2007). Cinnamomun cassia oil applied in its volatile form also inhibited conidial germination of $C$. gloeosporioides in vitro and reduced the lesion diameter on inoculated pepper fruits (Hong et al., 2015). Similarly, Moghaddam et al. (2013) found that essential oil from the many species, tested on three different fungus species from those that we tested, was most effective for inhibiting in vitro mycelial growth at a concentration $0.16 \%$. In Sarkhosh et al., (2017) found, some essential oil was primarily composed of these two chemical compounds, collectively representing $69.9 \%$ of the chemical constituents. Zambonelli et al. (1996) found that mint essential oil was most effective inhibiting mycelial growth of several fungi, including $F$. solani at a concentration of $0.16 \%$ in vitro.

It can attribute the increase of inhibition $\%$ of both radial growth and spore germination of tested fungi to the concentration of active components in the essential oils and their chemical structure are responsible for the aroma and antimicrobial activities in pepper's fruit. Because the essential oils yield greater antibacterial activity than their major constituents when separately tested (Burt, 2004). Moreover, the essential oils inhibit postharvest pathogens mainly due to their direct effect on the mycelial growth of the pathogens and 
spore germination by affecting the cellular metabolism of these pathogens (Serrano et al., 2005; Tzortzakis, 2007a, b; Regnier et al., 2010).

\section{CONCLUSION}

Based on obtained results, it can be concluded indicated that the tested essential oils had significant effects on the growth of studied fungi and the more effective of oils was Eugenia caryophyllata oil, then Eucalyptus globulus in all their concentrations, while Cinnamomum cassia and Zingiber officinale oils had a clear effective effect but, only at high concentrations of its. Moreover, Aspargillus niger relatively was more resistant compared to other ones.

\section{REFERENCES}

Ademoyegun, O. T., Fariyike T. A., and Aminu Taiwo R. B. (2011). Effects of poultry dropping on the biologically active compounds in Capsicum anuum L (Var. Nsukka yellow). Agricultural and Biology Journal of North America, 2(4):665 - 672.

Ashilenje, D.S. (2013). Learn How to Grow Pepper. Phoenix publishers Limited Nairobi, Kenya.

Balogun, O. S., Odeyemi, G. A. and Fawole O. B. (2005). Evaluation of the pathogenic effect of some isolates on fruits and seedlings of pepper (Capsicum spp.). Agric. Res \& Dev. 4 (2): 159 - 169.

Berke, T. (2002). The Asian Vegetable Research and Development Center Pepper Project. Proceedings of the 16th International Pepper Conference, Tampico, Mexico. November 10 - 12, Tamaulipas, Mexico. $1-16$.

Burt, S., (2004). Essential Oils: Their Antibacterial Properties and Potential Applications in Foods - a review. Int. J. Food Microbiol., 94: 223 - 253.

Caccioni, D. R. L., and Guizzardi, M., (1994). Evaluation of the potential of commercial postharvest application of essential oils to control citrus decay. J. Hortic. Sci. Biotech. 76: 935 - 940.

Duncan, D. B., (1955). Multiple-range and multiple-F tests. Biom. 11, 1- 42.

Hardenburg, R. E., Watada, A., and Wang, C. Y. (1990). The Commercial Storage of Fruits, Vegetables, Florist and Nursery Stocks (pp. 23-25). US Department of Agriculture, Agriculture Handbook No. 66. Washington, DC.

Hong, J. K., Yang H. J., Jung H., Yoon D. J., and Jeun Y. C. (2015). Application of volatile antifungal plant essential oils for controlling 
pepper fruit anthracnose by Colletotrichum gloeosporioides. Plant Pathology J.l., 31: $269-277$.

Howard, L. R., Talcott, S.T., Brenes, C. H. and Villalon, B. (2000). Changes in phytochemical and antioxidant activity of selected pepper cultivars (Capsicum species) as influenced by maturity. J.Agricultural and Food Chemistry, 48: 1713-1720.

Imelouane, B., Elbachiri A., Ankit M., Benzeid H., and Khedid K., (2009). Physicochemical compositions and antimicrobial activity of essential oil of eastern Moroccan Lavandula dentata. Int. J. Agr. Biol., 11: 113 - 118.

Kader, A. A. (2002). Postharvest Technology of Horticultural Crops. $\left(3^{\text {rd }}\right.$ Ed.) University of California Agriculture and Natural Resources Publication 3311. pp. 535.

Kaur J. and Arora D. (1999). Antimicrobial activities of species. Int. J. Antimicrob. Agents, 12: 257-262.

Kishore, G.K., and Pande S. (2007). Evaluation of essential oils and their components for broad-spectrum antifungal activity and control of late leaf spot and crown rot diseases in peanut. Plant Diseases, 91: 375-379.

Koul, O., Walia S., and Dhaliwal G. S., (2008). Essential oils as green pesticides: potential and constraints. Biopesticide. Int. 4, 63-84.

Lin, W. C. (2005). Quality of stored greenhouse sweet peppers influenced by storage temperatures and pre-harvest factors. Information and Technology for Sustainable Fruit and Vegetable Production (pp. 101110). FRUTIC 05: 12-16, Montpellier France.

Maalekuu, K., Elkind Y., Tuvia-Alkalai S., Shalom Y., and Fallik E. (2002). Quality evaluation of three sweet pepper cultivars after prolonged storage. Advances in Horticultural Science, 17: 187-191.

Macias, F. A., Castellano D., Oliva, R. M., Cross P., and Torres A., (1997). Potential Use of Allelopathic Agents as Natural Agrochemicals. Proc. Brighton Crop Prot. Conf, Weeds Brighton, UK, pp. 33 - 38.

Maqbool, M., Ali, A., Alderson, P.G., (2010). Effect of cinnamon oil on incidence of anthracnose disease and postharvest quality of bananas during storage. Int. J. Agr. Biol. 12: 516 - 520.

Meepagala, K. M., Sturtz G., and Wedge D. E., (2002). Antifungal constituents of the essential oil fraction of Artemisia drancunculus L. var. dracunculus. J. Agric. Food Chem. 50: 6989 - 6992.

Meir, S., Philosoph-Hadas S., Lurie S., Droby S., Akerman M., Zauberman G.. (1996). Reduction of chilling injury in stored avocado, 
grapefruit, and pepper by methyl jasmonate. Canadian J. of BotanyRevue Canadienne de Botanique, 74: 870-874.

Moghaddam, M., Pourbaige M., Tabar H. K., Farhadi N., and Hosseini S. M. A. (2013). Composition and antifungal activity of peppermint (Mentha piperita) essential oil from Iran. J. Essential Oil-Bearing Plants, 16: 506-512.

Naqui, S. H. A., Khan M. S. Y. and Vohora S. B. (1994). Antibac-terial, antifungal and anthelmintic investigation on Indian medicinal plants. Fitoterapia 62:221-228.

Paull, R. E. (1990). Chilling Injury of Crops of Tropical and Subtropical Origin. In C. Y. Wang (Ed.), Chilling Injury of Horticultural Crops (pp. 17-36). Boca Raton, FL: CRC Press.

Plotto, A., Roberts R. G., and Roberts D. D., (2003). Evaluation of plant essential oils as natural postharvest disease control of tomato (Lycopersicon esculentum). Acta Horticulture, 628:737 - 745.

Regnier, T., Combrinck, S., Du Plooy, W., and Botha, B., (2010). Evaluation of Lippia scaberrima essential oil and some pure terpenoid constituents as postharvest mycobiocides for avocado fruit. Postharvest Biol. Tec. 57: 176 - 182.

Sarkhosh A., Schaffer B., Vargas A. I., Palmateer A. J., Lopez P., and Soleymani A. (2017). In vitro evaluation of eight plant essential oils for controlling Colletotrichum, Botryosphaeria, Fusarium and Phytophthora fruit rots of avocado, mango and papaya. Plant Protect. Sci., 54: 153 - 162.

Sellamuthu, P. S., Sivakumar, D., Soundy, P., Korsten, L. (2013). Essential oil vapors suppress the development of anthracnose and enhance defense related and antioxidant enzyme activities in avocado fruit. Postharvest Biology and Technology, 81: 66 - 72 .

Serrano, O. I.; Hernández-Jover, T., and Martín-Belloso, O. (2007). Comparative evaluation of UV-HPLC methods and reducing agents to determine vitaminCin fruits. Food Chemistry, 105: $1151-1158$.

Smith, D. L., Stommel J. R., Fung R. W. M., Wang C. Y., and Whitaker B. D. (2006). Influence of cultivar and harvest method on postharvest storage quality of pepper (Capsicum annuum L.) fruit. Postharvest Biology and Technology, 42: 243-247.

Tzortzakis, N.G., (2007a). Maintaining postharvest quality of fresh produce with volatile compounds. Innovative Food Science and Emerging Technologies, 8:111-116. 
Tzortzakis, N.G., (2007b). Methyl jasmonate-induced suppression of anthracnose rot in tomato fruit. Crop Prot. 26: 1507 - 1513.

Vaughn, S. F., and Spencer, G. F., (1991). Volatile monoterpenes inhibit potato tuber sprouting. Potato J., 68: $821-831$.

Wilson, C. L., El Ghaouth A., Upchurch B., Stevens C., Khan V., Droby S., and Chalutz E., (1997a). Using an online UV-C apparatus to treat harvested fruit for controlling postharvest decay. Hort. Technology 7: $278-282$.

Wilson, C. L., Solar J. M., Ghaouth A. E. L., and Wisniewski M. E., (1997b). Rapid evaluation of plant extracts and essential oils for antifungal activity against Botrytis cinerea. Plant Dis. 8: $1204-1210$.

Zakari, B. G., Chimbekujwo I. B., Channya K. F. and Bristone B. (2015). In vitro antifungal activity of selected plant diffusates??? against postharvest fruit rot of pepper (Capsicum spp. L.) in yola ??. Global J. Biology, Agriculture and Health Sciences, 4(1):142-148.

Zambonelli, A., Zechini D'Aulerio A., and Bianchi A., Albasini A. (1996). Effects of essential oils on phyto-pathogenic fungi in vitro. $J$. Phytophathology, 144: 491 - 494.
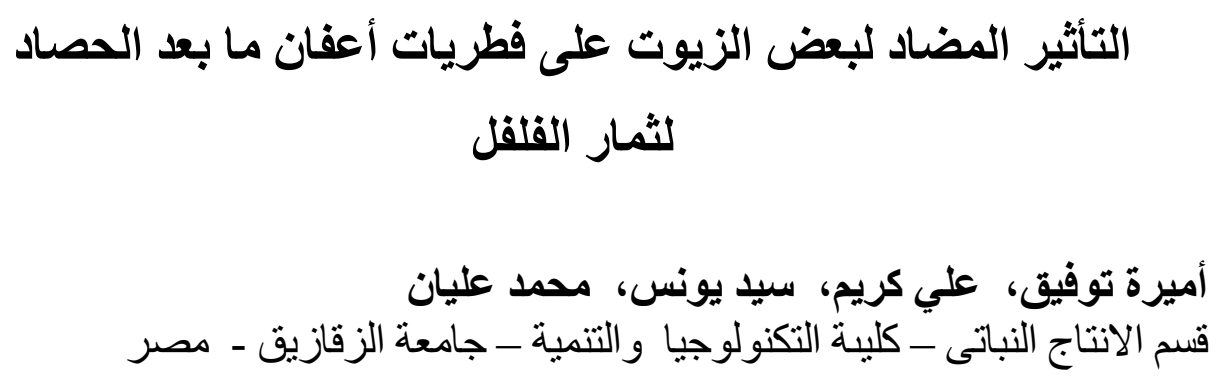

أجريت تجربة معملية باستخدام بعض الزيوت مثل زيت الكافور Eاف

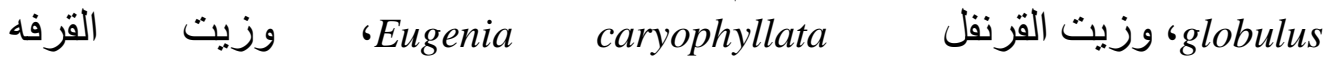

Cinnamomun cassia

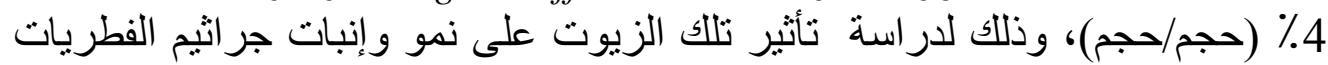

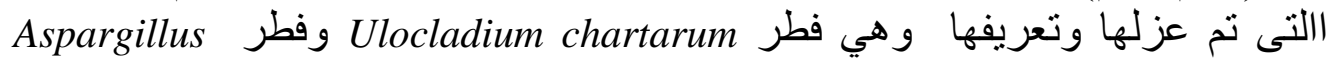

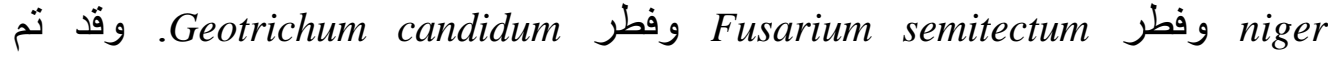




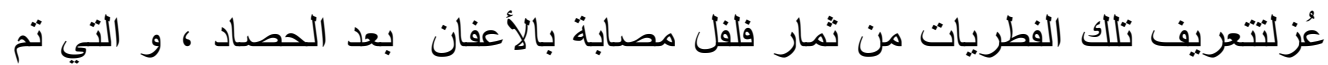

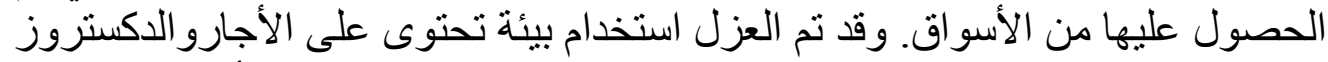

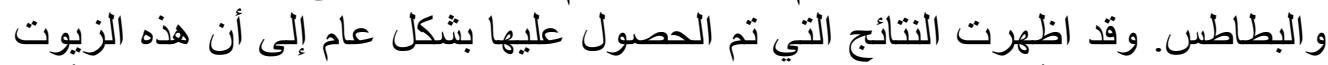

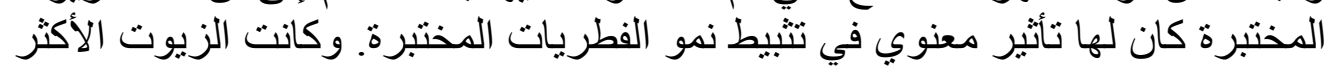

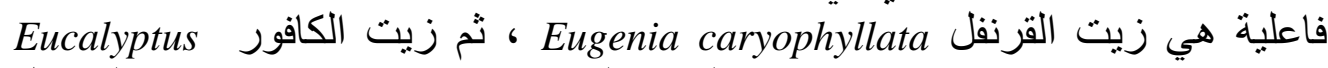

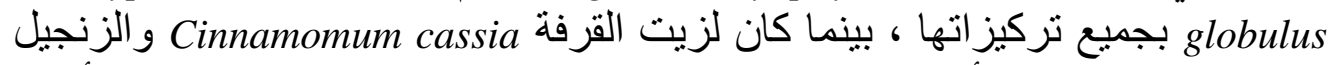

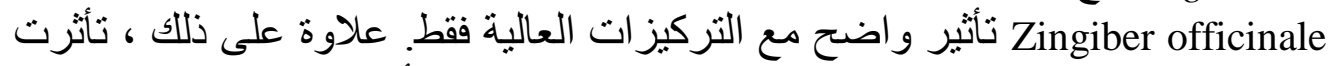
بعض الفطريات المختبرة بجميع الزيوت المستخدمة، وكان أكثر الفطريات مقاومة هو .Aspargillus niger التوصية: من النتائج السابقة نوصى باستخدام الزيوت العطرية كان فعالاً في تثبيط

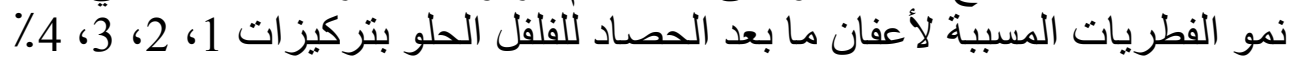

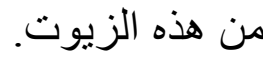
الكلمات الدالة: زيت النباتية ، ما بعد الحصاد. اعفان الثمار. الفلفل. 